\title{
Influence of Housing System and Number of Transported Animals on Transport-induced Mortality in Slaughter Pigs
}

\author{
Eva Voslářová ${ }^{1}$, Petr Chloupek ${ }^{1}$, Ladislav Steinhauser², Jan Havlíček ${ }^{3}$, Vladimír Večerek ${ }^{1}$ \\ ${ }^{1}$ Department of Veterinary Public Health and Toxicology, ${ }^{2}$ Department of Meat Hygiene and Technology, \\ Faculty of Veterinary Hygiene and Ecology, University of Veterinary and Pharmaceutical Sciences in Brno, \\ Czech Republic, ${ }^{3}$ Regional Veterinary Administration of the South Moravian Region, Czech Republic
}

Received June 24, 2009

Accepted September 8, 2009

\begin{abstract}
The study monitored the effect of the housing system and the number of animals transported together on transport-induced mortality of slaughter pigs in the Czech Republic in the period from 2004 to 2008. Concerning the type of housing during the fattening, the lowest mortality rate during the subsequent transport to slaughter houses was detected among pigs fattened on solid floor $(0.047 \%)$ and on deep bedding $(0.084 \%)$. The highest mortality during transport was detected among pigs fattened on fully or partially slatted floor $(0.139 \%)$, a significant difference $(p<0.01)$ was found compared to other housing types. Assessment of the influence of individual pig load size on mortality showed the lowest mortality among pigs transported in loads of up to 40 animals $(0.053 \%)$. Mortality during the transport in loads of the size of 41 to 120 animals was $0.130 \%$, and for loads of the size over 120 pigs the mortality rate was $0.156 \%$. These mortality rates are significantly higher $(p<0.01)$ compared to the load sizes of up to 40 animals.
\end{abstract}

Fattening pig, transportation, slatted floor, solid floor, deep bedding, welfare

The number of transport-induced deaths of animals on the way to the slaughter house indicates how animal welfare is secured during transport, but may be also influenced by pre-transport treatment (Malena et al. 2006, 2007; Večerek et al. 2006abcd; Voslářová et al. 2006, 2007ab). Warriss (1998b) reported that the transport-induced mortality of pigs ranged from $0.1 \%$ to $1.0 \%$ among different European countries. Von Altrock and von Holleben (1999) focused on the sudden deaths of pigs during transport, and they reported that due to the stress load of the pigs, sudden deaths caused by lactacidosis and cardiac shock occurred in $0.4 \%$ of the pigs during transport to the slaughter house. In the Czech Republic Večerek et al. (2006c) and Malena et al. (2007) explored transport-induced pig mortality on the way to the slaughter house, and they discovered a mortality rate of $0.107 \%$ and $0.108 \%$, respectively.

An important factor affecting the welfare of pigs during transport is the concentration of the transported animals. Warriss (1998a) discovered that higher stocking densities during pig transport are associated with higher mortality rates. Ritter et al. (2007) reported that the transport floor space had a major effect on transport losses and suggested that these losses be minimised to a floor space of $0.462 \mathrm{~m}^{2} /$ pig or larger. Lambooy and Engel (1991) proposed limiting the loading density to ca $232 \mathrm{~kg} / \mathrm{m}^{2}$ (ca $0.47 \mathrm{~m}^{2} / \mathrm{pig}$ ) for animal welfare and meat quality reasons. On the basis of measurements of the space needed for sternal recumbence and direct observations of pigs at different stocking densities, Warris s (1998a) reported that the minimum space required was equivalent to about $250 \mathrm{~kg} / \mathrm{m}^{2}$ for normal slaughter pigs of 90 to $100 \mathrm{~kg}$ live weight. Guise et al. (1998) found no evidence that the transport stocking density affected the carcass quality or welfare of 95-kg pigs on short journeys (3 h). Kim et al. (2004) detected a lower concentration of stress hormones in the low-density group than in the medium- or high-density group. Also detected was a significant interaction between the stocking density and transportation time in these blood

Address for correspondence:

Doc. Ing. Eva Voslářová, Ph.D

Department of Veterinary Public Health and Toxicology

Faculty of Veterinary Hygiene and Ecology

University of Veterinary and Pharmaceutical Sciences Brno

Palackého 1-3, 61242 Brno, Czech Republic

Tel.: +420541562 773

Fax: +420 541562790

E-mail: voslarovae $($ vfu.cz

http://www.vfu.cz/acta-vet/actavet.htm 
variables. Pale, soft and exudative (PSE) carcass appeared most frequently in the highstock density group. Also the number of pigs transported in one delivery affects the loading density and animal welfare. Gade and Christensen (1998) discovered that giving pigs more space during short transport did not make them lie down. On the contrary, there was continuous disturbance from the other pigs and with a space of 0.42 and $0.50 \mathrm{~m}^{2} / \mathrm{pig}$ they had difficulty in maintaining balance when the vehicle swerved at bends or on poor road surfaces.

The relationship between the rearing system and welfare of pigs is well documented, but the effect of the rearing system on transport mortality in pigs has not been studied yet. Some authors describe differences in behaviour during transport as a consequence of different rearing conditions (Geverink et al. 1999). Pigs reared in barren environment are likely to experience more stress during common pre-slaughter procedures including transportation, than pigs reared in enriched environment (de Jong et al. 2000; Gade 2008). Lebret et al. (2006) found non-significant effects of the rearing system on stress reaction at slaughter, but some meat quality indicators were influenced significantly. Effects of different housing conditions of slaughter pigs on pork quality characteristics are described also by e.g. Klont et al. (2001), Lambooij et al. (2004), Lebret et al. (2006), Gade (2008).

\section{Materials and Methods}

We evaluated the influence of the housing system and number of transported animals on the mortality of fattening pigs in connection with their transport for slaughter (i.e. death of pigs during transport or during lairage after transport) in one selected slaughter house in the Czech Republic in the period of 2004-2008. Data on the numbers of transported animals, origin of animals and the mortality rate were obtained from data of the state veterinary supervision and verified using data of the slaughter house operator.

To evaluate the effect of the number of pigs transported in the van, the deliveries were divided into 3 groups: up to 40 pigs in the delivery van, $41-120$ pigs and more than 120 pigs in the van. Data on the number of animals in the van were obtained from records of the slaughter house operator who entered detailed data about the deliveries of animals, including mortalities, from the area where the animals were received (platform and stables). The numbers of transported pigs and numbers of dead pigs were monitored and the ratio between the dead pigs and the total number of transported pigs was calculated and expressed as percentage. The effect of the number of transported pigs in the van on transportinduced pig mortality on the way to the slaughter house was derived from the monitored results.

To evaluate the effect of the rearing system, the floor types in the stables of supplier companies were monitored (fully or partially slatted floor, solid (concrete) floor with or without bedding). Data were obtained from the breeders. The numbers of pigs transported from each rearing system and numbers of pigs that died during transport were monitored and the ratio between the dead pigs and the total number of transported pigs was calculated and expressed in per cent. The effect of the rearing system on transport-induced pig mortality on the way to the slaughter house was derived from the monitored results.

The results were processed statistically using the $\chi^{2}$ test and statistical programme UNISTAT; the frequency was compared by means of contingency tables.

\section{Results}

The level of transport-induced mortality of pigs depending on the number of pigs transported in one load is displayed in Table 1.

Analysis of the effect of individual delivery size on mortality showed the lowest mortality in pigs transported in deliveries of up to 40 pigs $(0.053 \%)$. Transport-induced mortality was higher in pigs transported in deliveries of 41 to 120 animals, or over 120 pigs $(0.130 \%$ and $0.156 \%$, respectively). The difference was significant

Table 1. Dependence of the transport-induced mortality rate in slaughter pigs on the number of pigs in delivery

\begin{tabular}{|l|c|c|c|c|}
\hline \multirow{2}{*}{$\begin{array}{l}\text { Number of pigs } \\
\text { in one load }\end{array}$} & \multirow{2}{*}{$\begin{array}{c}\text { Number of pigs } \\
\text { transported }\end{array}$} & \multirow{2}{*}{ Number of loads } & \multicolumn{2}{|c|}{ Number of dead pigs } \\
\cline { 4 - 5 } & & Number & $\%$ \\
\hline$\leq 40$ & 65681 & 3003 & 35 & $0.053^{\mathrm{b}}$ \\
\hline $41-120$ & 186390 & 1903 & 242 & $0.130^{\mathrm{a}}$ \\
\hline$>120$ & 100983 & 580 & 158 & $0.156^{\mathrm{a}}$ \\
\hline
\end{tabular}

Values within a column with different superscripts differ significantly $(p<0.01)$

$$
(p<0.01) \text {. }
$$

Table 2 shows the effect of rearing system (floor type), used for housing during the fattening, on mortality during subsequent transport from breeding place to the slaughter house.

The lowest mortality rate was found in pigs transported from the solid (concrete) floor housing systems $(0.047 \%)$. Higher, but not significantly, was the mortality rate of pigs transported from the deep-bedding housing systems $(0.084 \%)$. Significantly 
Table 2. Dependence of the transport-induced mortality rate in slaughter pigs on the housing system

\begin{tabular}{|l|c|c|c|c|}
\hline \multirow{2}{*}{ Housing system } & \multirow{2}{*}{$\begin{array}{c}\text { Number of pigs } \\
\text { transported }\end{array}$} & \multirow{2}{*}{ Number of loads } & \multicolumn{2}{|c|}{ Number of dead pigs } \\
\cline { 4 - 5 } & 21117 & 865 & 10 & $0.047^{\mathrm{b}}$ \\
\hline Solid floor & 2174 & 1969 & 55 & $0.084^{\mathrm{b}}$ \\
\hline Deep bedding & 65194 & 2652 & 370 & $0.139^{\mathrm{a}}$ \\
\hline Slatted floor & 266743 & &
\end{tabular}

Values within a column with different superscripts differ significantly $(p<0.01)$ higher $(p<0.01)$, compared to those two types of rearing systems, was mortality rate of the pigs fattened on fully or partially slatted floors $(0.139 \%)$.

\section{Discussion}

Apart from being a considerable economic loss, mortality rate of pigs may serve as an indicator of pig welfare. Baumann and Bilkei (2002) reported that gastrointestinal tract disorders were the most frequently recorded cause of emergency-culling or mortality in fattening pigs followed by lesions which involved the respiratory system, diseases involving the urinary system, cardiovascular disorders, lesions involved the locomotor system, systemic infections, social stress and cannibalism. Pig losses are common also during their transport to the slaughterhouses. The data on transport-induced mortality in pigs were published by e.g. Warriss (1998b), von Altrock and von Holleben (1999), Večerek et al. (2006c) and Malena et al. (2007).

Influence of the transport loading density on animal welfare is not clear, published data on optimal animal density in the vehicle or on the effect of its exceeding vary (e.g. Lambooy and Engel 1991; Guise et al. 1998; Warriss 1998a; Kim et al. 2004; Ritter et al. 2007). Current legislation valid in EU countries since the $5^{\text {th }}$ of January 2007 requires all transported pig to have enough space to be able to lie down and stand up in their natural position. In order to comply with these minimum requirements, the loading density for pigs of around $100 \mathrm{~kg}$ should not exceed $235 \mathrm{~kg} / \mathrm{m}^{2}$ (Council Regulation (EC) No 1/2005). In our study, we monitored the effect of the number of pigs transported in a vehicle (loading density was kept within the limits required by regulations). Even when complying with regulation requirements, the density of pigs in a vehicle can vary according to the number of transported pigs, it can however be optimised by choosing a vehicle of appropriate size, or by using transportable dividers, keeping in mind that both too low or too high density of animals has a negative influence on the welfare of transported pigs (Gade and Christensen 1998; Warris s 1998a; Kim et al. 2004). Various numbers of pigs in one load are connected with different time requirements for loading, unloading and manipulation with pigs, i. e. with the time period when animals are exposed to an increased stress level connected with the transport. The transport-induced stress can be decreased when animals are handled by trained personnel, by choosing appropriate vehicle and devices for loading and unloading (e.g. Fischer 1996; Broom 2003, 2005; von Borell and Schaffer $2005)$, but the differences in handling groups of animals of different size cannot be disregarded. In our study, the effect of individual pig load size on the mortality level was found as follows: the lowest mortality was detected among the pigs transported in loads of up to 40 pigs $(0.053 \%)$, whereas loads transporting more than 120 pigs have shown the highest level of transport-induced mortality $(0.156 \%)$. Even though the transport was carried out by qualified personnel and vehicles complied with all regulation requirements, there was an effect of a higher stress level and its longer exposition during the loading and unloading of pigs that can not be completely avoided during transport by multi-level semi-trailer.

Because the rearing system has a significant influence on both welfare and health condition of pigs (Scott et al. 2006), it is reasonable to expect that the condition of pigs influenced by their housing during fattening will also show at the time of increased stress level connected with their transport to slaughter houses. Among the set of monitored pigs, the majority was fattened on fully or partially slatted floors. A negative effect of slatted floors on the welfare 
of pigs, particularly concerning the effect on locomotive apparatus, has been described by e.g. Jorgensen (2003) and KilBride et al. (2008). In our study, this effect has also been demonstrated by higher mortality of pigs transported after fattening to the slaughter house from slatted floor housing compared to pigs transported from solid floor housing. The reason can be possible health problems as well as more sensitive reaction to stress during pre-slaughter procedures connected to pig transportation for slaughter, as has been described by e.g. de Jong et al. (2000), Lebret et al. (2006) and Gade (2008) concerning pigs fattened in conditions with lower animal welfare. No significant difference has been found between mortality of pigs transported to the slaughter house after fattening on solid floor without bedding and in deep-bedding, although slightly lower mortality has been detected among pigs housed without bedding. This floor type is the most similar to the floor to which animals are exposed during the transport, which might be of some importance, however, not enough animals have been transported from this kind of housing to allow coming to a solid conclusion. As for the animals' welfare, breeding on deep-bedding has been found more effective (e.g. de Jong et al. 2000; Klont et al. 2001; Lambooij et al. 2004). Our study shows that better welfare of animals bred on solid floor without slats results in a better physical and psychical condition, leading to better coping with stress and therefore lower mortality during the transport to slaughter houses.

In conclusion, our study shows that together with previously described factors influencing transport-induced mortality of pigs, e.g. transport distance, season, stocking density, humane handling (Warriss 1998ab; Kim et al. 2004; Večerek et al. 2006c; Malena et al. 2007; Ritter et al. 2007), the number of pigs transported in one load and the housing systems during fattening can also be considered as important factors. Our study has shown a significant increase of mortality in loads over 120 animals and higher mortality was also connected with transport of pigs fattened on fully or partially slatted floors, compared to solid floor systems.

\section{Vliv typu ustájení a počtu přepravovaných zviřrat na úhyny prasat při přepravě na jatky}

V práci byl sledován vliv ustájení a počtu přepravovaných zvířat na úhyny jatečních prasat v souvislosti $\mathrm{s}$ jejich přepravou na vybrané jatky v České republice v období let 2004 - 2008. Z hlediska typu ustájení prasat při výkrmu nejmenší podíl uhynulých prasat při následné přepravě na jatky byl zaznamenán u výkrmu na bezroštových podlahách $(0,047 \%)$ a na hluboké podestýlce $(0,084 \%)$. Nejvyšší úhyny při přepravě byly zjištěny $u$ prasat vykrmovaných na plně nebo částečně roštových podlahách $(0,139 \%)$, byl zjištěn významný $(p<0,01)$ rozdíl ve srovnání s předchozími typy ustájení. Při hodnocení vlivu velikosti jednotlivých zásilek prasat na úroveň úhynů byl zjištěn nejnižší počet úhynů u prasat přepravovaných při počtu do 40 prasat $\mathrm{v}$ jedné zásilce $(0,053 \%)$. Při přepravě prasat s počtem přepravovaných prasat v dodávce 41 až 120 byly úhyny $0,130 \%$ a nad 120 prasat $\mathrm{v}$ dodávce $0,156 \%$. Tyto počty uhynulých prasat byly významně vyšší $(p<0,01)$ ve srovnání s přepravou prasat do 40 jedinců.

\section{Acknowledgements}

Supported by the Research Project No MSM6215712402 Veterinary aspects of food safety and quality.

\section{References}

Baumann B, Bilkei G 2002: Emergency-culling and mortality in growing/fattening pigs in a large Hungarian „farrow-to-finish“ production unit. Dtsch Tierarztl Wochenschr 109: 26-33

Broom DM 2003: Causes of poor welfare in large animals during transport. Vet Res Commun 27: 515-518

Broom DM 2005: The effects of land transport on animal welfare. Rev Sci Tech Off Int Epizoot 24: 683-691

Council Regulation (EC) No. 1/2005, on the protection of animals during transport and related operations and amending Directives 64/432/EEC and 93/119/EC and Regulation (EC) No. 1255/97 2005. Off J Eur Union L 3: 1-44 
De Jong IC, Prelle IT, Van De Burgwal JA, Lambooij E, Korte SM, Blokhuis HJ, Koolhaas JM 2000: Effects of rearing conditions on behavioural and physiological responses of pigs to preslaughter handling and mixing at transport. Can J Anim Sci 80: 451-458

Fischer K 1996: Transport of slaughter animals - Effects, weaknesses measures. Fleischwirtschaft 76: 521-526

Gade PB 2008: Effect of rearing system and mixing at loading on transport and lairage behaviour and meat quality: comparison of outdoor and conventionally raised pigs. Animal 2: 902-911

Gade PB, Christensen L 1998: Effect of different stocking densities during transport on welfare and meat quality in Danish slaughter pigs. Meat Sci 48: 237-247

Geverink NA, De Jong IC, Lambooij E, Blokhuis HJ, Wiegant VM 1999: Influence of housing conditions on responses of pigs to preslaughter treatment and consequences for meat quality. Can J Anim Sci 79: 285-291

Guise HJ, Riches HL, Hunter EJ, Jones TA, Warriss PD, Kettlewell PJ 1998: The effect of stocking density in transit on the carcass quality and welfare of slaughter pigs: 1 . Carcass measurements. Meat Sci 50: 439-446

Jorgensen B 2003: Influence of floor type and stocking density on leg weakness, osteochondrosis and claw disorders in slaughter pigs. Anim Sci 77: 439-449

Kilbride AL, Gillman CE, Ossent P, Green LJ 2008: Across-sectional study of the prevalence and associated risk factors for capped hock and the associations with bursitis in weaner, grower and finisher pigs from 93 commercial farms in England. Prev Vet Med 83: 272-284

Kim DH, Woo JH, Lee CY 2004: Effects of stocking density and transportation time of market pigs on their behaviour, plasma concentrations of glucose and stress-associated enzymes and carcass quality. Asian Australas J Anim Sci 17: 116-121

Klont RE, Hulsegge B, Hoving-Bolink AH, Gerritzen MA, Kurt E, Winkelman-Goedhart HA, De Jong IC, Kranen RW 2001: Relationships between behavioral and meat quality characteristics of pigs raised under barren and enriched housing conditions. J Anim Sci 79: 2835-2843

Lambooy E, Engel B 1991: Transport of slaughter pigs by truck over a long-distance - some aspects of loading density and ventilation. Livest Prod Sci 28: 163-174

Lambooij E, Hulsegge B, Klont RE, Winkelman-Goedhart HA, Reimert HGM, Kranen RW 2004: Effects of housing conditions of slaughter pigs on some post mortem muscle metabolites and pork quality characteristics. Meat Sci 66: 855-862

Lebret B, Meunier-Salaun MC, Foury A, Mormede P, Dransfield E, Dourmad JY 2006: Influence of rearing conditions on performance, behavioral, and physiological responses of pigs to preslaughter handling, carcass traits, and meat quality. J Anim Sci 84: 2436-2447

Malena M, Voslářová E, Tomanová P, Lepková R, Bedáňová I, Večerek V 2006: Influence of travel distance and the season upon transport-induced mortality in fattened cattle. Acta Vet Brno 75: 619-624

Malena M, Voslářová E, Kozák A, Bělobrádek P, Bedáňová I, Steinhauser L, Večerek V 2007: Comparison of mortality rates in different categories of pigs and cattle during transport for slaughter. Acta Vet Brno 76: S109-S116

Ritter MJ, Ellis M, Bertelsen CR, Bowman R, Brinkmann J, Dedecker JM, Keffaber KK, Murphy CM, Peterson BA, Schlipf JM, Woltert BF 2007: Effects of distance moved during loading and floor space on the trailer during transport on losses of market weight pigs on arrival at the packing plant. J Anim Sci 85: 3454-3461

Scott K, Chennells DJ, Campbell FM, Hunt B, Armstrong D, Taylor L, Gill BP, Edwards SA 2006: The welfare of finishing pigs in two contrasting housing systems: Fully-slatted versus straw-bedded accommodation. Livest Sci 103: 104-115

Večerek V, Grbalová S, Voslářová E, Janáčková B, Malena M 2006a: Effects of travel distance and the season of the year on death rates of broilers transported to poultry processing plants. Poult Sci 85: 1881-1884

Večerek V, Malena M jr, Malena M, Voslářová E, Bedáňová I 2006b: Mortality in dairy cows transported to slaughter as affected by travel distance and seasonality. Acta Vet Brno 75: 449-454

Večerek V, Malena M, Malena M, Voslářová E, Chloupek P 2006c: The impact of the transport distance and season on losses of fattening pigs during transport to the slaughterhouse in the Czech Republic in the period from 1997 to 2004. Vet Med 51: 21-28

Večerek V, Šímová V, Malena M, Voslářová E, Malena M jr 2006d: Effect of calf diseases on mortality during transport for slaughter. Acta Vet Brno 75: 625-630

Von Altrock A, Von Holleben K 1999: Sudden deaths in fattening herds on taking blood samples - Experiences from the practice. Berliner Munchener Tierarztl Wochenschr 112: 86-90

Von Borell E, Schaffer D 2005: Legal requirements and assessment of stress and welfare during transportation and pre-slaughter handling of pigs. Livest Prod Sci 97: 81-87

Voslářová E, Rubešová L, Večerek V, Pištěková V, Malena M 2006: Variation in the mortality rate of turkeys during transport to the slaughterhouse with travel distance and month. Berliner Munchener Tierarztl Wochenschr 119: 386-390

Voslářová E, Janáčková B, Rubešová L, Kozák A, Bedáňová I, Steinhauser L, Večerek V 2007a: Mortality rates in poultry species and categories during transport for slaughter. Acta Vet Brno 76: S101-S108

Voslářová E, Janáčková B, Vitula F, Kozák A, Večerek V 2007b: Effects of transport distance and the season of the year on death rates among hens and roosters in transport to poultry processing plants in the Czech Republic in the period from 1997 to 2004 . Vet Med 52: 262-266 
Warriss PD 1998a: Choosing appropriate space allowances for slaughter pigs transported by road: a review. Vet Rec 142: 449-454

Warriss PD 1998b: The welfare of slaughter pigs during transport. Anim Welf 7: 365-381 